\title{
System Management Innovation
}

\author{
Feiyang $\mathrm{Xu}^{1, *}$ \\ ${ }^{I}$ Ningbo Barstow Hanvos Kent school, Ningbo, Zhejiang province, China, 315000 \\ *Corresponding author. Email: xufeiyang@hanvos-kent.com
}

\begin{abstract}
With the development of the world economy, the competition between countries and enterprises is becoming more and more intense. With the development of large enterprises, more and more concentrated in enterprise innovation ability, and enterprise innovation management is the most important link in the innovation system. Enterprise innovation management is the necessary trend of future enterprise development and the development foundation of maintaining enterprise vitality and enterprise competitiveness. This paper is to find the process, successful trends, and effective way of innovation which apply to the enterprises. It analyzes the way to make research for the innovation. The main technology to research is the internet. The conclusion is that the enterprises need to apply innovation model to their work.
\end{abstract}

Keywords: managing, innovation, systematically, economy, business, manufacture

\section{INTRODUCTION}

With the development of the world economy, the competition between countries and enterprises is very serious. There is a huge amount of enterprises find a new way to develop themselves. In this way, innovation is an efficient way to improve the enterprise.

Are all of the innovation can benefit the enterprises? Do all enterprises would like to make the innovation? Are all of the innovations effective for all of companies in this society? The main theme is to systematically analyze the innovation and its process of the enterprises. Also, find the strand for the innovation and their benefits. Innovation can become a two sides sword. People need to use it at the right time. Innovation can help the company to earn more income. Innovation is very necessary for the whole society. Innovation can improve the whole society. The society will gradually develop because of the innovation, especially systematically innovation. When some small company does not use innovation appropriately, they can learn some of successful innovation model which can benefit itself.

\section{THE NECESSITY FOR ENTERPRISE INNOVATION MANAGEMENT}

\subsection{Easily Establish the Market Economy}

Since the reform and opening up, the method of national enterprise management has undergone great changes, changing from the earliest simple production management of state-owned enterprises to operational management. In the process of economic market evolution, many large enterprises have been pushed into the market. They are transformed into market entities with self-operation, responsible for profit and loss, self-development and self-accumulation, and gradually establishing a modern enterprise management system suitable for the market economy. All these also show that the system management mechanism is greatly strengthened, the degree of marketization is constantly improved, and the enterprise system is more and more complete. In order to adapt to the development of the current economic situation, enterprises must get rid of the influence of the old concepts, have the courage to innovate and correct, and establish a new management system, management system and methods.

\subsection{Necessity of World Economic Integration}

Since the 21st century, with the rapid economic growth of various countries in the world and the deepening of trade between countries, some countries 
will be affected by the change of economic exchange rates and interest rates [5]. As the market economy changes and the varying degrees are affected, which requires independent change by businesses, continuous enhancement through its own management, for example, Huawei phones in recent years are affected by foreign countries. Some imports of product parts are affected, It also directly leads to a straight decline in performance, which requires the enterprise itself to make adjustments. It can help to increase its own product supply chain development and application of development. Also, it can strengthen the market brand efficiency and constantly optimize your own products [4]. To escape from the current predicament, this requires a systematic management innovation for enterprises to make the adjustments. The above examples prove that enterprises have to adapt to social development if they want to grow continuously. They need to constantly adjust the market strategic layout and continue to improve the management system.

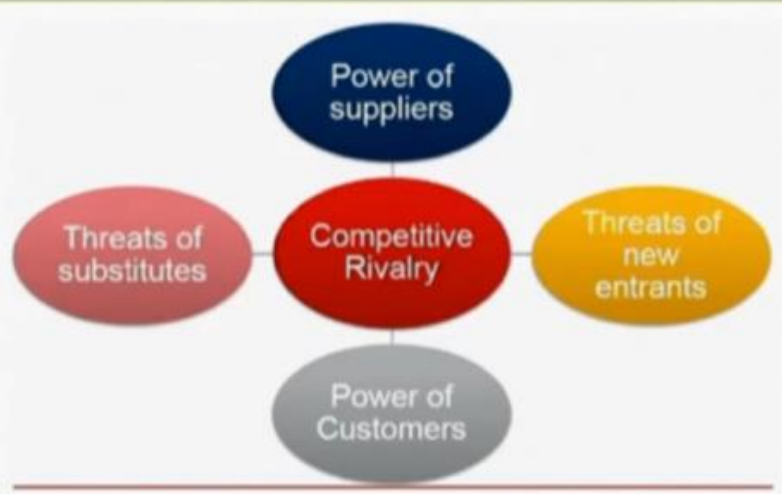

Figure 1. innovation model

\section{INNOVATIVE TRENDS OF SYSTEM MANAGEMENT DEVELOPMENT}

It is not difficult to see from the course of enterprise management reform in recent years that the future enterprise innovation management has the following development trends:

\subsection{Transformation from Maximizing Maximization to Sustainable Development of Enterprise}

As the only subject in enterprise management, the pursuit of profit maximization is an inevitable factor, which seriously hinders the development of enterprises, and even promotes the closure of enterprises, which is one of the important root causes of the death of the enterprise. Today, with the accelerating innovation speed of knowledge, technology and products, the sustainable development of growth has become an important issue.

Imagine: a big company "Nokia" sells old cell phone. Once worthy leading mobile phone industry cannot adapt to the current form development, it only pursue appearance renewal, but not to pursue their own research and development and combination. The final result of the final mobile phone brand will decline. The brand cannot keep up with the development of The Times, was eliminated by The Times.

The above example, if "Nokia" company in the earliest time, found the discovery of the market change, observation, found that the customer group requirement is higher and higher, with advance insight, people8 should try to do management innovation, the priority should be to solve the problem of market share, other brands, looking for their own shortcomings and defects, formulate solutions and discuss solutions, I think the enterprise should not be like this situation.

This process is: observe (contact acquisition) — to discover the market $\_$current situation (solution, brainstorming) _ Solution (Evaluation)

\subsection{Maintain a Competitive Edge}

The skills and knowledge of employees are important and valuable resources of the enterprise[6]. When in the face of knowledge competition challenges, enterprises need to combine more through coordination, strengthen cooperation, knowledge management, organizational learning, existing knowledge organization, personnel, processes and cooperation and management [2]. 


\section{Extension process:}

When consumer needs to buy the drinks from vending machine, the advertisement and guide signs can easily promote consumer to buy the drinks. So the customer found the retail machine and choose because the sales machine product style is rich and diverse, can choose more, but the customer before watching your advertising, he may be the first reaction to buy this kind of drink, so he traded, at this time, he consumed the Coca-Cola products, when he drinks, drink bottles need to recycle, reduce the manufacturing costs. Here is the question. Is this requires the producer to recycle or self-recycling, if the recycling can have monetary incentive, whether it can achieve consumer self-recycling. After the product communication, you can change the problems found by the product, to achieve a cycle purpose.

Set: Aware of the Need for — to Find Vending Machine — to Make Decisions _ Communication Select — Execution Deal — Get Items — Consumer Project — Processing Later Exchange Experience

As the above story summarizes, any kind of product needs to have a system of management, so as to think from the consumer point of view, detailed service, from purchase, purchase to purchase, the systematic service, I think this is the significance of enterprise management innovation, if a qualified employee, can consider these problems, that I think for the enterprise is no harm.

\section{THE CHARACTERISTICS OF THE SYSTEM INNOVATION MANAGEMENT}

Systemic refers to the system that seeks the focus of innovation management and evaluates innovation achievements [1]. As is well known, an enterprise is a complex system, and the elements in each system connect and interact. An innovative management system can provide standards for enterprises.

If a product is established, people consider it in multi-dimensions:

Supplier - Platform - Solution - Customer Experience - value
Customer - process - organization innovation
capture - supply chain - location - network -
brand - multi-dimensional analysis
consideration, and that is systematic management.

\section{THE MAJOR STAGE IN THE INNOVATION MANAGEMENT PROCESS}

\subsection{Problem is found}

You can control the negative factors that you should limit or improve. Found and confirm the dissatisfaction. Analysis and summarize some deficiencies:

Consumer dissatisfaction with the products and services of enterprises;

Dissatisfaction of ordinary employees of the enterprise with the enterprise salary system, performance evaluation and employment system;

- Dissatisfaction at various levels within the enterprise;

. Crisis and challenges faced by enterprises;

. Investor dissatisfaction with the performance of the enterprise;

\subsection{Find countermeasures}

In order to eliminate the above dissatisfaction, enterprises need to conduct an innovative management system. There are generally three options:

. Reform of the enterprise management system

. Introducing the mature management technology

. Innovation by innovation

\section{CONCLUSION}

Systematically innovation can benefit the whole society while people need to use it at the appropriate time. The strand of whole society gradually begins to make innovation for their enterprises especially for those old companies. Even though the process of innovation is very complicated, the final consequence is positive for most the companies. Innovation can help to make the improvement for the whole country.

\section{AUTHORS' CONTRIBUTIONS}

This paper is independently accomplished by the author.

\section{ACKNOWLEDGMENT}

First of all, I would like to thank the professor very much for giving us a lecture in his busy work. Every class is very serious and rigorous. Each topic is carefully prepared and very attractive. In addition, there will be group activities in class, which greatly improves the cooperation ability with classmates. I learned a lot of analytical methods and models in the class. These methods can help me make a better preparation for 
future synthesis. All of all, i want to thank my professor again.

\section{REFERENCES}

[1]. Katie, Jensen. Systemic perspectives in business organization. CHRON. Web.

[2]. Morten, Dalum. What is challenge based development. Acadian. Web. April 7, 2019.

[3]. Will, Purcell. The importance of innovation in business. Blog. Web. October 31, 2019.

[4]. Walked M, abdelnasser. Innovation in the economy and society. Ahramonline. Web. 31 January, 2020.

[5]. Will, Kenton. Economic integration. Investopedia. Web. March 31, 2021.

[6]. Bob, House. Embracing innovation to sustain a competitive edge. Inc. web. October 30, 2017. 